\title{
A MAGYAR NYELVÛ́ SPORTMOTIVÁCIÓS SKÁLA (H-SMS) VALIDÁCIÓJA ÉS EREDMÉNYEI
}

\author{
PAIC RÓBERT ${ }^{1}$ - KAJOS ATTILA ${ }^{1,2}$ - MESZLER BALÁZS ${ }^{1}-$ \\ PRISZTÓKA GYÖNGYVÉR ${ }^{1}$
}

\author{
${ }^{1}$ PTE TTK Sporttudományi és Testnevelési Intézet \\ ${ }^{2}$ Budapesti Corvinus Egyetem Gazdálkodástudományi Kar \\ E-mail: paic@gamma.ttk.pte.hu
}

Beérkezett: 2017. július 17. - Elfogadva: 2018. február 1.

Online megjelenés: 2018. május 17.

\begin{abstract}
Háttér és célok: 2016-ban a Sportmotivációs Skála javított verziója (SMS2) kapcsán végzett forditási és validációs próbálkozásaink során megállapítottuk, hogy a magyar nyelv sajátosságai, valamint a magyar sportolók gondolkodásának eltérö vonásai nem feltétlenül teszik lehetốvé a sportmotivációs skálák egy az egyben történó fordítását. Ezért az eredeti irányvonalat és az eredeti elméleti keretrendszert, vagyis az önmeghatározás-elméletet (SDT - Self-determination theory) és annak faktorait (belsố motiváció, integrált, identifikált, introjektált, külsố szabályozás, amotiváció) megtartva, a magyar viszonyokhoz igazított, a nemzetközi eredményekkel mégis alapvetôen összevethetố instrumentum megalkotását túztük ki célul.

Módszer: Az eredeti, angol nyelvü SMS2 skála kialakításához használt 61 item fordítását követôen annak 500 fós sportolói mintán történô validálására került sor feltáró és magyarázó faktoranalizis révén. A mintát 319 férfi és 181 nö alkotta, átlagos életkoruk 21,16 év (szórás 6,45) volt.

Eredmények: A feltáró faktorelemzéssel kapott magyar nyelvú Sportmotivációs Skála (H-SMS) 22 tételének faktorstruktúrája az eredeti (SMS2) méröeszköz faktorszerkezetéhez nagyon hasonló maradt. A H-SMS végsố, megerösitó faktorelemzéssel kialakitott verziója 6 faktort és 19 tételt foglal magába, melyeket egy 7 fokú skálán válaszol meg a kitöltố. A végleges változat két különbözố modell közül került kiválasztásra, és maximálisan megfelel a pszichometriai instrumentumokkal szemben támasztott érvényességi $(C M I N / d f=1,77$; $S R M S R=0,042 ;$ RMSEA =0,040; PCLOSE =0,983; $N F I=0,953 ; T L I=0,973 ; C F I=0,979)$, valamint megbizhatósági (Cronbach alfa =0,79-0,89; CR =0,80-0,94; AVE =0,65-0,89; AVE > MSV) kritériumoknak. Az eredetitôl eltéröen a végsố struktúrában az intrinzik motivációt mérố faktort két alfaktorra osztottuk: az észlelt kompetenciára (kognitív) és az önhatékonyság növelésére (effektív) irányuló intrinzik motivációra.
\end{abstract}

Konklúzió: Az eredmények alapján biztonsággal kijelenthetố, hogy a skála messzemenókig alkalmas a sporthoz köthetô motivációk mérésére, valamint a nemzetközi eredményekkel való összehasonlításra is.

Kulcsszavak: sportmotivációs skála, validitásvizsgálat, pszichometriai skála 


\section{BEVEZETÉS}

A szakirodalom a motivációt azokkal a személyiségfaktorokkal, szociális tényezókkel és kognitív folyamatokkal azonosítja, amelyek akkor kerülnek előtérbe, amikor a személy önmaga számára fontos feladatot vállal, másokkal való versengésbe kezd, és a tökéletességre törekszik (Roberts, 1992). Más megközelítésben a motiváció az erôfeszítés iránya és intenzitása (Sage, 1977 idézi Weinberg és Gould, 2011). Újabb meghatározás szerint: „A motiváció ... a viselkedés és a magatartás kiváltásában, szabályozásában és fenntartásában szerepet játszó tényezôk összességét jelenti” (Gyömbér és Kovács, 2012:96). A motiváció a nevelési-tanulási folyamat egyik lényegi és nélkülözhetetlen eleme, amely felelôs a viselkedés beindításáért, meghatározza annak irányát és fenntartja egészen a cél elérése pillanatáig (Tóth, 2015). A résztvevó-központú szemlélet alapján a motivált magatartásmód elsốdlegesen az egyéni tulajdonságok funkciója. A sportolók motivált viselkedésének elsôdleges meghatározói a személyiségjegyek, a szükségletek és a célok. A résztvevô-központú szemlélet ellentéte a helyzetcentrikus szemlélet, amely kimondja, hogy az egyén motivációját mindig valamilyen szituáció határozza meg. A sportra és a sportpszichológiai gyakorlatra mégis a kettô ötvözete, az interakciós szemlélet jellemzô, amelyben a résztvevô és az adott helyzet interakciója és együttes hatása határozza meg az egyén motivációját (Weinberg és Gould, 2011).

A sportolásnak, fizikai aktivitás végzésének számos jótékony hatása van, úgymint az emelkedett fittségi állapot és vitalitás, a megnövekedett önbecsülés és a betegségek hiánya (Bouchard, Bell és Haskell, 2007; Pelletier, Vallerand és Sarrazin, 2007). Emellett nem elhanyagolható az a tény, hogy a fizikai aktivitás prevenciós, egészségmegôrzô hatással rendelkezik, és kihatással van az életminôség alakulására is (Dishman és Buckworth, 2001; Camliguney, Mengutay, és Pehlivan, 2012). Ennek ellenére többen valamilyen okból felhagynak az aktív sportolással (Sarrazin, Boiché és Pelletier, 2007). A motiváció a sporttevékenységeknek is hangsúlyos eleme, ugyanis hatással van a verseny- és edzôi viselkedésformákra, a kitartásra, a tanulásra és a teljesítményre (Duda, 1989), valamint a sportban való részvételre és kitartásra is (Hagger és Chatzisarantis, 2007; Standage és Ryan, 2012; Vallerand, 2007; García Calvo, Cervelló, Jimenéz, Iglesias, és Moreno Murcia, 2010).

\section{Az önmeghatározás elmélete (Self-Determination Theory)}

Az önmeghatározás elmélete az emberi motiváció sportra és testmozgásra is alkalmazható olyan keretrendszert mutat be, amely az individuum autonómia-, kompetenciaés a valahova tartozás érzetét állítja az emberi kitartás, kreativitás és a megnövekedett teljesítmény elérésének középpontjába. Az önmeghatározás-elméletre alapozva a sportmotiváció olyan komplex jelenség, melynek alapján a sportolónak számos oka lehet a sporttevékenység végzésére. Ez megnyilvánulhat a külsố tényezôk hatására, mint például az anyagi juttatás/díjazás; az értékelés; az edzô vagy a szülôk nyomása (Ryan és Deci, 2007). Ugyancsak motiválhatják a sportolókat belsố tényezôk, mint a kíváncsiság; a tanulási és fejlôdési késztetés; a vágy képességeik fejlesztésére (Pelletier, Rocchi, Vallerand, Deci, és Ryan, 2013). A belsố motiváció hatására a személy önként, 
saját elhatározása alapján végzi a választott tevékenységet, külsô anyagi elismerés vagy ösztönzés nélkül (Deci és Ryan, 1985). Ebból kiindulva azok a sportolók, akik azért végeznek sporttevékenységet, hogy folyamatosan túlszárnyalják önmaguk teljesítményét, belsôleg (intrinzik motiváció) motiváltak a sportáguk iránt (Pelletier, Fortier, Vallerand, Tuson, Brière, és Blais, 1995). Természetesen az edzók is nagymértékben befolyásolhatják a sportoló motivációját, erôsíthetik a belsô ösztönzóket (Megeau és Valerrand, 2003). Az önmeghatározás elmélete hat mini elméletból tevôdik össze. Ezek a CET (Cognitive Evaluation Theory), az OIT (Organismic Integration Theory), a COT (Causality Orientations Theory), a BPNT (Basic Psychological Needs Theory), a GCT (Goal Contents Theory) és az RMT (Relationship Motivation Theory). A motiváció sportolásra és testmozgásra kifejtett hatása szemszögébôl az egyik legfontosabb a CET, a kognitív értékelés elmélete, amely alapján az egyén viselkedését a belsố és külsố környezetének megváltoztatására érzett szükséglete nézôpontjából vizsgáljuk. Eszerint az egyén viselkedésmódját az önmeghatározottság szükséglete, azaz a kontroll alóli függetlenség motiválja. Vagyis a kompetencia és az autonómia szemszögébốl és kölcsönhatásaiból következtetnek az intrinzik motivációra. Az elmélet integrálja az empirikus kutatások tapasztalatait a külsố és belsô tényezôk intrinzik motivációra gyakorolt hatásaival, valamint annak az egyén viselkedésére ható következményeivel (Deci és Ryan, 1985, 2000). Az SMS az önmeghatározás elméletén, és azon belül a kognitív értékelés modelljének elméleti összetevôin alapul.

\section{Magyar sportmotivációs kérdốivek}

Bollók, Takács, Kalmár és Dobay (2011) a motiváció mérésére saját szerkesztésú kérdôívet hozott létre, amely egyike volt az 5 faktort vizsgáló skálának. A faktorok a következôk: megjelenés; szociális tudatosság és alkalmazkodás; egészséges étkezés; sport és sportolási szokások; függôségek. A sport és sportolási szokások faktorainak mérésére egy 69 itemból álló, 4 alfaktorra bontott kérdőívet alkalmaztak. A 4 alfaktor: a verseny és a sikerorientált motiváció; fizikai fittség, egészség és sportszerú attitûd; külsô alkalmazkodás; valamint a hedonisztikus motivációs faktor. A felmért 600 elemszámú minta alapján megállapították, hogy a lány tanulók fơleg külsô motivátorok alapján sportoltak. Az aktív tanulók körében nagyobb jelentôséggel bírtak a motiváló tényezôk, mint az inaktívaknál. Az aktív tanulók úgy vélekedtek, hogy a sportteljesítmény fogja elvezetni óket a sikerhez. Mikulán és Pikó (2012) a fiatal sportolók káros szenvedélyeinek sportmotivációs vonatkozásában lefolytatott vizsgálatukban a sportmotiváció mérésére saját készítésû, 18 itemból álló ötfokozatú skálát alkalmaztak, amelyet az eredeti SMS alapján szerkesztettek. A sportmotivációk csoportosításához faktoranalízist használtak, amely alapján értelmezték a motivációs struktúrát, majd a meghatározott változók segítségével összesített motivációs faktorokat alkottak. Az így létrejött 4 faktor a „siker- és gyózelemorientáció”, a ,jó alak és egészség”, a „megfelelni a külsô elvárásoknak” és a „barátok, szórakozás” volt. A Cronbach-alfa értékük felsorolási sorrendben: 0,88; 0,77; 0,68 és 0,72 .

Munkácsi, Kalmár, Hamar, Katona és Dancs (2012) a tornaedzôk motivációs módszereit mérték szintén saját készítésû, 8 itembôl álló kérdôívvel, amely eredményei 
alapján arra következtettek, hogy a motiváció folyamatos fenntartása szükséges a magas teljesítmény eléréséhez.

A sportmotiváció és a flow élmény összefüggéseinek vizsgálatára alkalmazta Szemes és Harsányi (2015) a sportmotivációs skála általuk kialakított változatát, amely megfelelt az eredeti SMS skálának, és amely tartalmazta a külsô motiváció minden faktorát. Kutatásuk során megállapították, hogy erôs kapcsolat van az intrinzik tapasztalatkeresés és az autotelikus élmény között; viszont a kapcsolatok többsége gyengén korrelált egymással. Eredményeik alapján többek között azt is megállapították, hogy szignifikáns korreláció van az atléták belsô motivációja és a feladatközpontúság érzete között.

Szemes, Harsányi és Tóth (2016) tanulmányában az eredeti Sportmotivációs Skála (SMS) fordításával és visszafordításával, valamint annak ellenôrzésével létrehozták a magyar sportmotivációs skála saját verzióját, amely a Vallerand-féle hierarchikus modell alapján mérte az intrinzik és az extrinzik motivációt; az intrinzik elsajátítást; a tökéletességre törekvést; a tapasztalatkeresést; az extrinzik külsô szabályozást; az introjekciót, identifikációt, valamint az amotivációt is. Vizsgálatukban 115 különbözô sportágú sportoló felmérése során megállapították, hogy a leginkább belsôleg motiváltak a küzdôsportokat ûzô sportolók. Tanulmányaikhoz a skálák kapcsán a feltáró faktoranalízis (KMO és Bartlet-tesz) és a megbízhatóságvizsgálat (Cronbach-alfa) eredményeit mellékelték.

\section{A sportmotivációs skála eredeti (SMS) és javított (SMS2) változata}

A kutatásunk alapjául vett eredeti sportmotivációs skálát (SMS) két nyelven, angolul (Pelletier és mtsai, 1995) és franciául (Brière, Vallerand, Blais és Pelletier, 1995) is validálták a szerzôk. Több vizsgálat elemezte a skála strukturális és validitási összetevőit (Li és Harmer, 1996; Jackson, Ford, Kimiecik és Marsh, 1998; Chatzisarantis, Hagger, Biddle, Smith, és Wang, 2003), és alkalmazhatónak találta a sportolás iránti motiváció mérésére. Ezenkívül a skála lehetôvé tesz további összehasonlításokat is: használható mindkét nem (Li és Harmer, 1996); különbözô szexuális irányultságú résztvevôk (Zamboni, Crawford, és Carrico, 2008); csapat- és egyéni sportolók (Pelletier és mtsai, 2007) sportmotivációjának mérésére is. A skála adaptált változata (Zahariadis, Tsorbatzoudis, és Grouis, 2005) alkalmas a gyermekek sportmotivációjának felmérésére. Széles körben használva alkalmasnak bizonyult az edzésen való kitartás (Pelletier, Fortier, Vallerand és Brière, 2001); a fizikai aktivitásban való részvétel (Standage, Duda és Ntoumanis, 2003); az önbecsülés (Zamboni és mtsai, 2008) és a sporttal kapcsolatos pozitív érzelmek (Pelletier és mtsai, 1995) prognosztizálására. Szintén következtetéseket lehetett levonni a skála használatával a kiégés (Cresswell és Eklund, 2005) és a sportolók lemorzsolódásának (Pelletier és mtsai, 2001) elôrejelzésére. Az eredeti SMS skálát számos nyelvre lefordították és validálták, így például megtalálható bolgár (Chantal, Guay és Dobreva Martinova, 1996), görög (Doganis, 2000), spanyol (Nuñez, Albo, Navarro és Gonzalez, 2006), portugál (Bara, Andrade, Miranda, Núñez, MartínAlbó és Ribas, 2011) és német nyelven is (Burtscher, Furtner, Sachse és Burtscher, 2011). Ezek a skálák azonban nem tartalmazták az önmeghatározás elméletének ke- 
retrendszerében leírt integrált szabályozást mint az önmeghatározott viselkedésforma egyik elemét (Pelletier és Sarrazin, 2007; Pelletier és mtsai, 2013). Pelletier és munkatársai (1995) az SMS elsố verziójában az alábbi faktorokat használták a sportmotivációs skála kapcsán. Az intrinzik (belsô) motivációt három alskálára osztották, mely taxonómiát elméleti alapon Vallerand, Pelletier, Blais, Brière, Sènècal és Vallibres (1992) alapozták meg tanulmányukban:

(a) Motiváció a tanulás iránt: felfedezés, kíváncsiság, tanulási célok, alapvetô tanulási és megértési vágy. A sportolók egyes új mozgásformák, edzésmódszerek megtanulása iránt érezhetnek belsố tanulási motivációt.

(b) Motiváció a teljesítmény/eredmény iránt: feladatorientáltság vagy feladatközpontúság. Ez a fajta motiváció valamilyen eredmény elérésére vagy alkotásra ösztönöz.

(c) Motiváció a tapasztalatszerzés iránt: a sportolók, akik azért versenyeznek, hogy átéljék a verseny okozta izgalmakat, ezzel a fajta motivációval rendelkeznek.

Ezek a dimenziók megegyeznek a Vallerand-féle hierarchikus modell a tudásra, a fejlôdésre és a tapasztalatszerzésre irányuló szabályozás doménjeivel (Vallerand, 1997).

Az extrinzik (külsô) motivációt a következô faktorokra osztják:

(d) Külsô szabályozás: ebben az esetben a sportoló valamilyen külsố hatás (pl. anyagi javak, szülôi megfelelés kényszere, edzônek való megfelelés kényszere) miatt úzi a sporttevékenységet.

(e) Introjekció: a külsô motivációs tényezô internalizálódik; már nem kell jelen lennie ahhoz, hogy kiváltsa a motivációt. Ezek a magatartásformák belsô hajtóerôvel is alátámasztottak, mint például a búntudattal és/vagy az aggodalommal. Azok képviselik az ezzel a motivációs bázissal rendelkezók csoportját, akik azért sportolnak, mert szégyellik, hogy nincsenek jó formában.

(f) Identifikáció/azonosítás: Az alany ilyenkor a sporttevékenységet fontosnak értékeli, s már nem választáson alapuló tevékenységként úzi. Tevékenységét ebben az esetben a személyiségfejlôdése részeként tekinti.

(g) Amotiváció/motiváció hiánya: A sportolót ilyenkor az inkompetencia érzete és a kontroll hiánya jellemzi. Nem éreznek sem belsô, sem külsố motivációt.

Az eredeti SMS-t két kutatásuk során szerkesztették meg, amelyekból az elsôben a franciáról lefordított kérdéseket egy n = 593 (319 férfi és 274 nô) elemszámú és 19,2 átlag életkorú egyetemi sportolói mintán tesztelték. A sportolók között egyéni (atlétika, úszás, tájfutás) és csapatsportolók (rögbi, amerikai foci, kosárlabdázás, röplabdázás, labdarúgás és jégkorong) is szerepeltek. Az elemzés során megerôsítô faktorelemzést (CFA) végeztek, amely alapján a skála mutatói gyengének bizonyultak: $\chi^{2}$ / $\mathrm{df}=1,94, \mathrm{GFI}=0,94, \mathrm{AGFI}=0,92, \mathrm{RMR}=0,048, \mathrm{NFI}=0,92$. A második vizsgálatban 50 labdarúgó-játékossal töltették ki a kérdôívet kétszer 5 héten át, amelynek eredményeiból arra következtettek, hogy a korrelációk elfogadhatók voltak 0,58-tól 0,84-ig terjedô értékekkel. A teszt-reteszt korreláció értéke 0,70 volt, amely alapján megállapították, hogy közel azonos értékú a francia skálával $(0,70)$, amelynek köszönhetốn a skála temporális stabilitását elfogadták (Pelletier és mtsai, 1995).

Az új sportmotivációs skálák megjelenése és a meglévô eredeti skála kritikai szemlélete arra késztette az eredeti SMS szerzôit, hogy újragondolják, módosítsák és javítsák saját sportmotivációs skálájukat, és ennek eredményeként alkották meg az új, 
átdolgozott SMS2 sportmotivációs skálát. Az SMS nem tartalmazta az önmeghatározás elméletének keretrendszerében megjelenô integrált szabályozás faktorát mint az önmeghatározott külsố motiváció egyik alapvetô faktorát. Ezen kívül az intrinzik motiváció három (a tanulás, a tapasztalatszerzés és a tudás megszerzésére irányuló belsô motiváció) faktorát összevonták, amely egy faktorként jelent meg az új, átdolgozott SMS2-ben (Pelletier és mtsai, 2013). A végsô, 18 itemes skálát 2 lépcsốben szerkesztették meg, ahol az elsô célja különbözô motivációs skálák itemeinek felhasználásával (SMS: Pellettier et al, 1995; GMS - Globális motivációs skála: Pelletier és Dion, 2007; TEOSQ - Feladat- és egoorientáció a sportban: Chi és Duda, 1995; SWLS - Az élettel való megelégedettség skála: Diener, Emmons, Larsen, és Griffin, 1985; valamint az SV - Szubjektív vitalitás skála: Ryan és Frederick, 1987) egy olyan kérdéshalmaz létrehozása, amelybốl a késôbbiekben összeáll a használható kérdôív. Az így létrehozott, 61 kérdésból álló „item pool”-t n = 412 fôs sportolói mintán tesztelték, amelyben egyéni és csapatsportolók is reprezentáltak voltak. Megerôsítô faktoranalízis, megbízhatóságvizsgálat és korrelációanalízis elvégzése után alakították ki azt a 18 kérdésból álló kérdôívet, amely az új és a régi itemek közül kiragadott elemeket is tartalmazott. A megerôsítô faktoranalízist $n=290$ fôs sportolói mintán végezték el. Az eredmények alapján megállapították, hogy a 6 faktoros modell - amely egyezik az önmeghatározás elméletének keretrendszerével - adatai az elégséges szinttől a nagyon jó illeszkedésekig terjedtek. A faktorok kialakítása így elméleti alapon történt, amit a statisztikai adatok megerôsítettek: RMSEA = 0,07; RMSEA 90\% CI = 0,05-0,08; CFI = 0,94; NFI = 0,90; $\mathrm{TLI}=0,92$. Az itemek faktorainak faktorsúlya 0,47-tól 0,95-ig terjedt (Pelletier és mtsai, 2013). A skálát más nyelveken is validálták, így például az SMS2 kínai verziója három vizsgálati szakaszból álló kutatás során nyerte el a végsố 18 kérdéses formáját, ahol az elsố tanulmányban nem sikerült az integrált és az identifikált faktorokat megkülönböztetni. Szintén akadályokba ütköztek a szerzók a kínai nyelv különlegessége és a „jutalom” szó interpretálása miatt, végül a második és a harmadik vizsgálat megfelelô modellt és illeszkedési mutatókat eredményezett (Li, Kawabata, és Zhang, 2016). Munkacsoportunk a sportmotivációs skála második verziójával (SMS2) végzett fordítási és validálási eljárás során számos olyan nehézségbe ütközött, amelyek miatt az egész validálási procedúrát újra kellett gondolni. Történt mindez azért, mert a feltáró faktoranalízis során a magyar nyelvú változatban az intrinzik és identifikált itemek mérésére használatos kulcsszavak esetében a fordítás két jelentésében nagyon közeli szó fogalmazódott meg, így ezek a faktorok keveredtek (Paic, Kajos és Prisztóka, 2016).

\section{Egyéb sportmotivációs skálák}

Mivel az eredeti SMS nem tartalmazta az önmeghatározás elméletének keretrendszerében megtalálható introjektált szabályozás faktort, Mallett, Kawabata, Newcombe, Otero-Forero és Jackson (2007) megalkották az azonos keretrendszerre és azonos faktorok használatára épülô SMS-6 skálát. Ez 24 itemból áll, tartalmazza az integrált szabályozás faktort és 4 itemet minden egyes faktor esetében. A skála valiabilitási mutatói elfogadhatók voltak $(\mathrm{CFI}=0,909 ; \mathrm{NNFI}=0,898 ; \mathrm{SRMR}=0,070 ; \mathrm{RMSEA}=0,052$ és AIC $=197,639)$. A belsố konzisztencia Cronbach-alfái magasabb értéket mutattak 
0,70-nél, átlagban 0,78 volt (Mallet és mtsai, 2007). Ezzel szemben Lonsdale, Hodge és Rose (2008) egy teljesen új faktorokból álló kérdôív validálását tûzte ki célul, és 4 tanulmány keretében megalkották a szintén sportmotivációt mérô BRSQ (Behavior Regulation in Sport Questionairre) kérdôívet. A kérdôív két formája közül az egyik három különálló faktorra bontotta a belsô motivációt, míg a másik egy faktorként kezelte. A valiabilitási mutatók a következóképpen alakultak: BRSQ-8 (8 faktor): Scaled $\chi^{2}=982,15$ RMSEA = 0,060; RMSEA 90\% Cl = 0,06-0,07 CFI = 0,97; TLI = 0,97, BRSQ-6 (6 faktor): Scaled $\chi^{2}=601,44$; RMSEA $=0,07$; RMSEA $90 \% \mathrm{Cl}=0,06-0,08 ; \mathrm{CFI}=0,97$; $\mathrm{TLI}=0,97$.

\section{A magyar SMS és verziói}

A Sportmotivációs Skála (SMS) magyar nyelvre történô adaptálására már korábban is történtek kísérletek: Járai nemek szerinti bontásban vizsgálta a sportmotivációt (2004), de dolgozatában (2006) a megerôsítő faktoranalízis eredményei alapján a magyar változat gyenge illeszkedést mutatott az eredeti faktorstruktúrára (GFI =0,78, AGFI = $\left.0,734, \mathrm{CFI}=0,83, \chi^{2}=619,9, \mathrm{df}=329\right)$. A leggyakrabban hivatkozott magyar nyelvú SMS validációt Tsang, Szabo, Soos és Bute (2005) alkották meg egy kulturális összehasonlító tanulmány során. Vizsgálatukban 3 tényezôt (faktort) mértek: a motiváció hiányát, a belsố motivációt és a külsô motivációt. A vizsgált magyar nyelvú mintát $\mathrm{n}=252$ résztvevô adta, melyek átlagéletkora 13.03 év $(\mathrm{SD}=1.02)$ volt. A validálás során csupán a megbízhatósági értékek publikálására került sor (Cronbach-alfa $=0,65$ és 0,85 közöttiek voltak). Erre a kérdôívre alapozva több magyar nyelvú tanulmány született.

Bognár, Géczi, Vincze és Szabó (2009) a fiatal jégkorongozók és labdarúgók motivációs profiljának vizsgálatához a fent említett magyar nyelvú Sportmotivációs Skálát használták. Vizsgálatuk során megállapították, hogy a sportolók általánosan alacsony amotivációval és magas belsố motivációval rendelkeznek. Géczi, Vincze, Koltai és Bognár (2009) tanulmányukban, amely 4 csapatjáték fiatal elit sportolóinak megküzdési módjait, sportmotivációját és észlelt motivációs környezetét vizsgálta, szintén a Tsang és munkatársai (2005) által publikált Sportmotivációs Skála magyar változatát használta, ahol az elkülönített három faktor a belsố és külsô motiváció, valamint az amotiváció voltak. Kutatásuk alapján arra következtettek, hogy a fiatal elit sportolók sportmotivációja mind a 3 faktor alapján különbséget mutat a férfi és a nối sportolók között. A férfi sportolók alacsonyabb amotivációval és magasabb belsố motivációval rendelkeztek, mint a lány csapatjátékosok.

Benczenleitner, Bognár, Révész, Paksi, Csáki és Géczi (2013) is ugyanezt a kérdôívet használta a kalapácsvetốk motivációjának és észlelt motivációs környezetének vizsgálatában. Kutatási eredményeikbôl kiderült, hogy a kis elemszámú vizsgálati minta ( $n=23)$ alacsony amotivációval és közepes szintû külsố és belsố motivációval rendelkezett. Csáki, Fózer-Selmeci, Bognár, Szájer, Zalai és Géczi (2016) fiatal labdarúgók felmérését végezték a magyar nyelvú validált sportmotivációs kérdôívvel, amely alapján a játékosok motivációs bázisa kiegyensúlyozottnak bizonyult a külsô és a belsố motiváció faktorainak eredményei alapján. Az amotiváció alacsony szintje jellemezte az általuk lekérdezett mintát. Szemes, Vig, Géczi, Patócs, Sipos és Tóth (2017) a mo- 
tiváció és az észlelt motivációs környezet összefüggéseit vizsgálták. Adatfelvételükhöz szintén a Tsang és munkatársai (2005) által kialakított magyar nyelvú sportmotivációs skálát használták, amely 3 faktort különített el. Munkájukban összefüggéseket találtak az észlelt motivációs környezet feladatorientáltsága és a belsô motiváció elsajátítási faktora között. Továbbá azt is megállapították, hogy az énközpontú motivációs környezet kapcsolatban áll a külsô motiváció külsô szabályozás faktorával. A fenti kutatások mindegyikének közös jellemzője, hogy nem térnek ki a skálák megbízhatósági és illeszkedésvizsgálati eredményeinek közlésére.

\section{MÓDSZER}

A pszichometriai skálák fordítására a szakirodalom több megoldást is ismer. A Vallerand (1989) által kidolgozott, és a fizikai aktivitás területén Banville, Desrosiers és GenetVolet (2000) által adaptált fordítási eljárás alapjait követtük. A validitási eljárás kapcsán az eredeti SMS2 skála kialakításának módszertanát használtuk fel. Munkánk újdonságtartalmát az adja, hogy nemcsak az SMS2 kérdôív végleges itemeit használtuk fel, hanem a Pelletier és munkatársai (2013) publikációjában közzétett teljes ún. „item poolt”. Az item pool a skála végleges változatának megalkotását szolgáló elôzetesen kialakított és ellenôrzött kérdéseket jelenti (Clark és Watson, 1995), amelyek olykor nem is annyira tartalmukban, hanem feltevésük módjában térnek el egymástól. Az item pool összes kérdésének lekérdezését követôen, a kutatási célok és a statisztikai módszerek segítségével kerül kialakításra a végleges forma (Kavussanu, Stanger és Boardley, 2013).

\section{A skála itemeinek fordítása}

A skála fordításának elsô lépése az elôzetes verzió kialakítása, amely a fordítás, visszafordítás módszertanára épült a teljes 61 item esetében. Elsố lépésben - a megfelelô nyelvi jártasság birtokában a forrás és a célnyelvben egyaránt - önállóan lefordítottuk magyarra az eredeti skála itemeit. Ezt követốn egyeztettük az esetleges különbségeket, majd két további fordító visszafordította azt az eredeti forrásnyelvre. Az eljárás során megállapítást nyert, hogy az eredeti és a visszafordított skála itemei amellett, hogy nem mutattak egészen pontos egyezést, tartalmukban mégis lefedik az eredeti változatot.

Második lépésben az elôzetes verzió értékelésére szakértői munkacsoport kialakítására került sor sportpszichológus bevonásával, aki megállapította, hogy a fordítások megfelelőek.

A végleges skála kialakítását követôen, annak tantermi, kiscsoportos tesztelésére került sor a PTE Sporttudományi és Testnevelési Intézet sportszakos hallgatóinak körében. Ennek során a tesztet kitöltôk nyelvtani, formai vagy a megfogalmazás érthetôségével kapcsolatos visszajelzéseit is figyelembe vettük, így alakult ki a végsố skála. A kérdôív tartalmi validitását a szakértôii csoport véleményezése jelentette. 


\section{A skála érvényessége és megbizhatósága}

Egy adott skála konstrukciós vagy fogalmi érvényességét a feltáró (EFA), valamint megerôsítô faktoranalízissel (CFA) szükséges vizsgálni. A faktorelemzés fontos feltétele, hogy metrikus változókat használjunk. Esetünkben mindegyik indikátort 7 fokozatú Likert-skálán mértük, így megfeleltünk ennek a feltételnek (Malhotra és Simon, 2008). A szükséges mintaelemszám a végsố faktorstruktúra esetében meghaladta a faktoranalízis során Bentler és Chou (1987) által javasolt „n / q > 5” szabályt, ahol „n” az elemszámot, „q” a modellben becsült paraméterek számát jelenti. A végsố modellben a paraméterek száma 19 , míg a két részminta elemszáma $n 1=250$ és n $2=250$ volt.

A belsô megbízhatóság kapcsán három mutatót, a Cronbach-féle alfát, a composit reliabilityt (CR - az indikátorhoz tartozó fogalmi megbízhatósági mutató) és az átlagos magyarázott variancia (AVE) értéket használtuk fel. Az elvárt küszöbérték az elsô két mutató esetében 0,70, míg az utóbbi esetében 0,50 (Bagozzi és Yi, 1988; Fornell és Larcker, 1981; Hair, Black, Babin, Anderson, és Tatham 2010).

A modell illeszkedésvizsgálata során Chi-négyzet próbát, valamint annak standardizált változatát, a CMIN/df ( $\chi 2 /$ degree of freedom) abszolút illeszkedési mutatót használtuk, amely a modell jóságát ahhoz a helyzethez viszonyítja, amikor „nincs modell” (Byrne, 2000). A szintén használt „RMSEA” (Root Mean Square Error of Approximation) olyan, a rezidiumok elemzésén alapuló mutató, amely segítségével a megfigyelt korreláció/kovariancia és a reprodukált értékek közötti eltérésekre végezhetünk hipotézistesztelést. A szintén használt illeszkedési mutatók közül az NFI (Normed Fit Index), a TLI (Tucker-Lewis Index) és a CFI (Comparative Fit Index) inkrementális vagy komparatív mutatókat használtuk, amelyek egy, az elemzés során specifikált alapmodellhez viszonyítanak (Neumann-Bódi, 2012). A standardizált reziduális négyzetes középérték (Standard Root Mean Square Residual, SRMR) a minta és a hipotetikus modell kovarianciamátrixa közötti eltérés négyzetgyökének standardizált formája (Bagozzi és Yi, 1988).

A mutatók elemzése során a szakirodalom által javasolt alábbi kritériumok kerültek elfogadásra. A CMIN/df mutató esetében Marsh és Hocevar (1985), valamint Carmines és McIver (1981) kritériumként az enyhébbnek számító 5 alatti, míg Bentler (1990) a szigorúbb 3 alatti hányadost jelöli meg. Az RMSEA esetében Byrne (2000) alapján a 0,06 alatti mutató tekinthetố jónak, de már a 0,08 alatti eredménnyel rendelkezô modellt el lehet fogadni.

Hu és Bentler (1999) iránymutatásai alapján az NFI, TLI és CFI mutatók mindegyike esetében 0,9-es érték felett beszélhetünk jó, és 0,95 fölötti mutató esetében remek illeszkedésrôl. Az SRMR esetében az illeszkedést a 0,08-nál kisebb érték jelenti.

A mintavétel során összesen 560 sportoló adatai kerültek begyújtésre papír alapú kérdőivek segítségével. A sportolókat pécsi és Pécs környéki csapat-, illetve egyéni sportolók alkották, akik heti rendszerességgel sportolnak különbözó szinten. Az eredeti mintából a késôbbiekben a kitöltési hibák, alacsony életkor és értelmezhetetlen válaszok miatt összesen 60 kérdôív került kizárásra, amely révén végül 500 fố alkotta a vizsgálati mintát. A vizsgálatban részt vevôk körébe összesen 319 férfi és 181 nô került, az átlagos életkoruk 21,16 év (szórás 6,45) volt. A legtöbben, 158-an (31,6\%) a 20-23 éves korosztályt képviselték, amelyet a 18-19 éves $(\mathrm{n}=145 ; 29 \%)$, a 15-17 éves 
$(\mathrm{n}=114 ; 22,8 \%)$, a 24-35 éves $(\mathrm{n}=61 ; 12,2 \%)$ és a 35 évnél idôsebbek $(\mathrm{n}=22 ; 4,4 \%)$ követtek. A részt vevố sportolók 66\%-a (330 fó) csapatsportoló, míg a maradék $34 \%$ (170 fô) egyéni sportoló volt. A mintába kerülô sportolók átlagos edzésszáma 4,5 hetente, szórása 2,18. A sportolók közel fele heti 4 vagy 5 edzésen vesz részt.

\section{EREDMÉNY}

A különbözô tudományterületeken is elterjedt megoldásnak (Conners, Sitarenios, Parker és Epstein, 1998; Lyden és mtsai, 1999; Petrides és Furnham, 2000; Mészáros, Csigás, Ádám, Hevesi és Oláh, 2014) és az eredeti skála kialakításának (Pelletier és mtsai, 2013) is megfelelôen, a mintánkat véletlenszerúen kétfelé osztottuk, hogy az egyik felén feltáró, míg a másik felén megerôsítô faktorelemzést végezzünk. A faktoranalízis elôtt ellenôrzésre került, hogy a fontosabb mutatók kapcsán a két részminta megfeleltethetô-e egymásnak. Ennek eldöntésére a két részmintát Wilcoxon-próbával és a kategorikus változó (sportág) esetében khi-négyzet próbával vizsgáltuk (a paraméteres változók egyike sem volt normál eloszlású, amelyet Kolgomorov-Smirnov és Shapiro-Wilk tesztek erôsítettek meg). Ennek eredményeit a 1. táblázat tartalmazza, amelyból jól látszik, hogy a két részminta azonos alapsokasághoz tartozik. A két paraméteres változó esetében t-próba elvégzésére is sor került, ahol hasonló eredményt kaptunk.

1. táblázat. A teljes minta és az analízisre szétválasztott részminták adatai

\begin{tabular}{llcccc}
\hline & Teljes minta & $\begin{array}{c}\text { 1. (EFA) } \\
\text { részminta }\end{array}$ & $\begin{array}{c}\text { 2. (CFA) } \\
\text { részminta }\end{array}$ & $\begin{array}{c}\text { Különbség vizsgálat } \\
\text { eredménye }\end{array}$ \\
\hline Mintaelemszám (n) & 500 & 250 & 250 & \\
Nemek & férfi & $319(63,8 \%)$ & $160(64 \%)$ & $159(63,6 \%)$ & $\mathrm{F}=0,009(\mathrm{sig}=0,926)$ \\
& nó & $181(37,2 \%)$ & $90(35 \%)$ & $91(37,4 \%)$ & \\
Életkor & átlag & 21,16 & 21,08 & 21,25 & $\mathrm{Z}=-0,801(\mathrm{sig}=0,423)$ \\
& szórás & 6,45 & 6,20 & 6,71 & \\
Heti & átlag & 4,50 & 4,50 & 4,51 & $\mathrm{Z}=-0,718(\mathrm{sig}=0,473)$ \\
edzésszám & szórás & 2,18 & 2,30 & 2,01 & $\mathrm{~F}=8,37(\mathrm{df}=12 ;$ \\
Sportág & & & & & $\mathrm{sig}=0,756)$ \\
\hline
\end{tabular}

\section{Feltáró faktoranalizis}

A feltáró faktoranalízisre Pelletier és munkatársai (2013) által eredetileg is használt 61 item felhasználásával került sor. Figyelembe véve a kiinduló elméletet, az eredeti faktor struktúráját, a faktorsúlyokat, az egyes itemek tartalmának kritikus értékelését, az egymáshoz nagyon hasonló (pl. az AMOT2 „Már úgy érzem, hogy nem érhetek el sikereket ebben a sportágban” és az AMOT7 „Olyan érzésem van, hogy már nem tudok sikeres lenni ebben a sportágban”), egymással túlságosan korreláló elemek jelenlétét, végül a kérdések számát 22-re sikerült redukálni. A 22 kérdés kiadta az eredeti hat faktort, de az egyes faktorokban található kérdések mennyisége eltérést mutatott. 
Elemzésre a szokásos fókomponensanalízist alkalmaztuk, amelyet Promax-rotáció révén ellenôriztünk. A feltáró faktoranalízis végsố itemeit és faktorstruktúráját a 2. táblázat tartalmazza. A táblázatba a Promax-rotáció miatt a faktoranalízis „pattern” mátrixa került.

2. táblázat. A feltáró faktoranalízisének „pattern” mátrixa

\begin{tabular}{lrrrrrr}
\hline & \multicolumn{5}{c}{ Faktor } \\
Változó & \multicolumn{1}{c}{1} & \multicolumn{1}{c}{2} & \multicolumn{1}{c}{4} & \multicolumn{1}{c}{5} & \multicolumn{1}{c}{6} \\
\hline INTRI15 & $\mathbf{0 , 8 7 7}$ & $-0,020$ & 0,004 & $-0,049$ & $-0,057$ & $-0,015$ \\
INTRI9 & $\mathbf{0 , 8 2 9}$ & $-0,012$ & 0,046 & $-0,008$ & $-0,015$ & $-0,111$ \\
INTRI10 & $\mathbf{0 , 8 0 3}$ & $-0,036$ & 0,114 & $-0,026$ & 0,066 & $-0,069$ \\
INTRI16 & $\mathbf{0 , 7 7 6}$ & 0,037 & $-0,060$ & 0,018 & $-0,121$ & 0,158 \\
INTRI18 & $\mathbf{0 , 7 7 4}$ & 0,022 & $-0,057$ & 0,009 & 0,061 & 0,004 \\
INTRI17 & $\mathbf{0 , 7 1 9}$ & 0,028 & $-0,049$ & 0,066 & 0,109 & 0,077 \\
INTEG3 & 0,107 & $\mathbf{0 , 8 6 7}$ & $-0,020$ & 0,042 & $-0,075$ & $-0,038$ \\
INTEG2 & 0,084 & $\mathbf{0 , 8 2 1}$ & $-0,009$ & 0,002 & 0,055 & $-0,078$ \\
INTEG4 & $-0,100$ & 0,818 & 0,072 & $-0,083$ & $-0,057$ & 0,004 \\
INTEG5 & $-0,068$ & 0,689 & 0,001 & 0,028 & 0,152 & 0,128 \\
EXTER7 & 0,009 & 0,022 & $\mathbf{0 , 9 3 0}$ & $-0,116$ & 0,034 & $-0,005$ \\
EXTER9 & $-0,029$ & 0,052 & $\mathbf{0 , 8 8 0}$ & 0,026 & $-0,010$ & 0,045 \\
EXTER8 & 0,046 & $-0,028$ & $\mathbf{0 , 8 1 1}$ & 0,092 & 0,003 & 0,023 \\
AMOT7 & 0,017 & $-0,029$ & $-0,054$ & $\mathbf{0 , 9 2 9}$ & $-0,048$ & 0,039 \\
AMOT4 & $-0,018$ & 0,082 & $-0,037$ & $\mathbf{0 , 8 0 5}$ & 0,052 & 0,044 \\
AMOT8 & $-0,013$ & $-0,100$ & 0,100 & $\mathbf{0 , 8 0 1}$ & 0,043 & $-0,073$ \\
IDENT11 & 0,013 & $-0,013$ & 0,070 & 0,021 & $\mathbf{0 , 9 0 2}$ & $-0,032$ \\
IDENT10 & 0,067 & $-0,078$ & 0,070 & $-0,017$ & $\mathbf{0 , 8 7 0}$ & 0,005 \\
IDENT9 & $-0,052$ & 0,147 & $-0,128$ & 0,037 & $\mathbf{0 , 8 0 4}$ & 0,000 \\
INTRO7 & $-0,014$ & $-0,049$ & $-0,012$ & $-0,010$ & 0,032 & $\mathbf{0 , 8 8 2}$ \\
INTRO9 & $-0,027$ & 0,069 & 0,113 & 0,133 & $-0,138$ & 0,867 \\
INTRO8 & 0,048 & $-0,053$ & $-0,065$ & $-0,161$ & 0,134 & 0,730 \\
\hline
\end{tabular}

Megjegyzés: Fôkomponensanalízis Promax-rotációval (6 iteráció). A végleges változatban maradó elemek félkövér, míg az onnan végül az illeszkedésvizsgálat miatt kivettek faktorsúlyait dôlt betûvel szedtük.

Az EFA során a KMO (Kaiser-Meyer-Olkin) mutató értéke 0.885 volt, amely Sajtos és Mitev (2007) alapján jónak tekinthetô; emellett a Barlet-teszt eredménye is szignifikáns volt. A hat faktor összességében a variancia 71,51\%-át magyarázta, ami hasonló skálák esetében magasnak tekinthetô. A modellben észrevehetô, hogy az egyes faktorok esetében az itemek faktorsúlyai minden esetben magasak.

\section{Megerôsitố faktoranalizis}

A megerôsítô faktoranalízishez az IBM SPSS AMOS 24-es programját használtuk. Az eredeti, 22 itemból álló struktúra nem felelt meg a validitási kritériumoknak (RMSEA $=0.073[0.064-0.082] ;$ PClose $=p<0.001$ ), így a faktor itemeinek faktorsúlyai és a prog- 
ram modifikációs javaslatai alapján a modell folyamatosan módosításra került mindaddig, amíg az elfogadható tartományba nem került. Ennek köszönhetốen kialakult a 19 itembốl álló konstruktum, amely az elsố vizsgálati modellt alkotta. A vizsgált modellben az integrált és introjektált motiváció faktorainak elemszáma csökkent le kettốre. Ez a modell megfelelt az illeszkedés statisztikai kritériumainak (lásd 3. táblázat), viszont az itemek részletesebb áttekintése során megállapítottuk, hogy az intrinzik motiváció kapcsán megmaradt kérdések közül három a technikai elemek elsajátítására, míg további három a kognitív tanulásra kérdez rá. Fontos visszatérnünk rá, hogy az eredeti SMS esetében nem kezelték a szerzôk egységes konstrukcióként az intrinzik motivációt, ezért végül egy olyan látens intrinzik faktor létrehozása mellett döntöttünk, amely az elôzốekben felsorolt három-három kérdést két külön faktorban - az önhatékonyság növelésére irányuló pszichomotoros (technikák elsajátítása) tanulás közben érzett effektív irányultságú intrinzik motivációs; és a kognitív tanulás intrinzik motivációs faktorában - méri. A másodrendû faktorstruktúra kialakítása tehát elméleti alapon került létrehozásra, mivel feltételezésünk szerint jobban megragadja az intrinzik motiváció valódi természetét.

A második modell kialakítása után a két modell illeszkedésének összehasonlítását végeztük el. Ennek eredményeit a 3. táblázat foglalja össze. Eredményként megállapítottuk: annak ellenére, hogy mindkét modell megfelel az illeszkedésvizsgálat kritériumainak, a második modell egyértelmúen jobb az elsônél, mivel minden egyes, a módszertani részben bemutatott vizsgálati kritérium kapcsán jobb értékeket mutatott, ezáltal pontosabban illeszkedett a tesztmintára. A két modell közötti különbséget jól mutatja például a TLI értéke, amely a második modell esetében a ,jó”-ból a „remek” illeszkedési tartományba került.

3. táblázat. A modellek illeszkedésvizsgálati eredményei

\begin{tabular}{lccccccc}
\hline & CMIN/df & SRMR & RMSEA & PCLOSE & NFI & TLI & CFI \\
\hline $\begin{array}{l}\text { Modell 1 (6 intrinzik) } \\
\text { Tesztmintán }(\mathrm{n}=250)\end{array}$ & 1,85 & 0,053 & 0,058 & 0,113 & 0,904 & 0,940 & 0,953 \\
& & & & & & & \\
$\begin{array}{l}\text { Modell 2 (6 intrinzik } \\
-2 \text { alfaktorban) }\end{array}$ & & & & & & & \\
Tesztmintán $(\mathrm{n}=250)$ & 1,69 & 0,050 & 0,053 & 0,341 & 0,914 & 0,951 & 0,962 \\
\hline
\end{tabular}

A másodrangú modell elfogadása kapcsán egy további kritériumot is megvizsgáltunk a végsố döntés elôtt. Mégpedig, hogy van-e létjogosultsága a különbözô alfaktoroknak, különösen annak tükrében, hogy a közöttük lévố korreláció magasnak tekinthetô (lásd 4. táblázat). Ennek érdekében összehasonlításnak vetettük alá a két modell azonos faktorának és a két alfaktorának válaszait.

A 6 itemes intrinzik motiváció átlaga 4,90, míg az effektív intrinzik motivációjé 4,70, a kognitív intrinzik motivációjé pedig 5,10. Vagyis a kognitív és effektív intrinzik motiváció különbsége 0,4 pont, ami komoly szignifikáns különbséget jelent a két változó között $(\mathrm{Z}=-8,194 ; \mathrm{p}<0,001)$. Emellett ráadásul a hatfokozatú intrinzik motiváció és az egyes alfaktorok közötti 0,2 pontos eltérések is szignifikánsak $(\mathrm{Z}=-8,194 ; \mathrm{p}<0,001)$. 
Mindezek miatt döntöttünk a két alfaktor megtartása mellett. Az így kialakult végleges faktorstruktúrát az 1. ábra, a modell megbízhatóságvizsgálatának eredményét pedig a 4. táblázat tartalmazza.

4. táblázat. A H-SMS végsô faktorainak 9+ó korrelációi, átlaga és szórása

\begin{tabular}{lcccccccccc}
\hline Változó & INTRI6 & E_INT & K_INT & INTEG & IDENT & $\begin{array}{c}\text { INT- } \\
\text { RO }\end{array}$ & EXTR & AMOT & Átl. & Szórás \\
\hline INTRI6 & 1 & $0,924^{*}$ & $0,931^{*}$ & $0,566^{*}$ & $0,644^{*}$ & $0,521^{*}$ & $-0,038$ & $-0,329^{*}$ & 4,90 & 1,30 \\
E_INT & & 1 & $0,728^{*}$ & $0,424^{*}$ & $0,485^{*}$ & $0,385^{*}$ & $-0,019$ & $-0,321^{*}$ & 4,70 & 1,42 \\
K_INT & & & 1 & $0,466^{*}$ & $0,529^{*}$ & $0,456^{*}$ & $-0,072$ & $-0,348^{*}$ & 5,10 & 1,37 \\
INTEG & & & & 1 & $0,640^{*}$ & $0,422^{*}$ & 0,059 & $-0,084$ & 4,87 & 1,47 \\
IDENT & & & & & 1 & $0,484^{*}$ & $0,196^{*}$ & $-0,051$ & 4,77 & 1,38 \\
INTRO & & & & & & 1 & $-0,057$ & $-0,377^{*}$ & 5,40 & 1,37 \\
EXTR & & & & & & & 1 & $0,433^{*}$ & 2,59 & 1,50 \\
AMOT & & & & & & & & 1 & 2,21 & 1,73 \\
\hline
\end{tabular}

Megjegyzés: *p<0,001 (INTRI6 = Intrinzik motiváció hat eleme együtt; E_INT = Effektív Intrinzik; K_INT = Kognitív Intrinzik; INTEG = Integrált; IDENT = Identifikált; INTRO = Introjektált; EXTR = Külsố szabályozás; AMOT = Amotiváció)

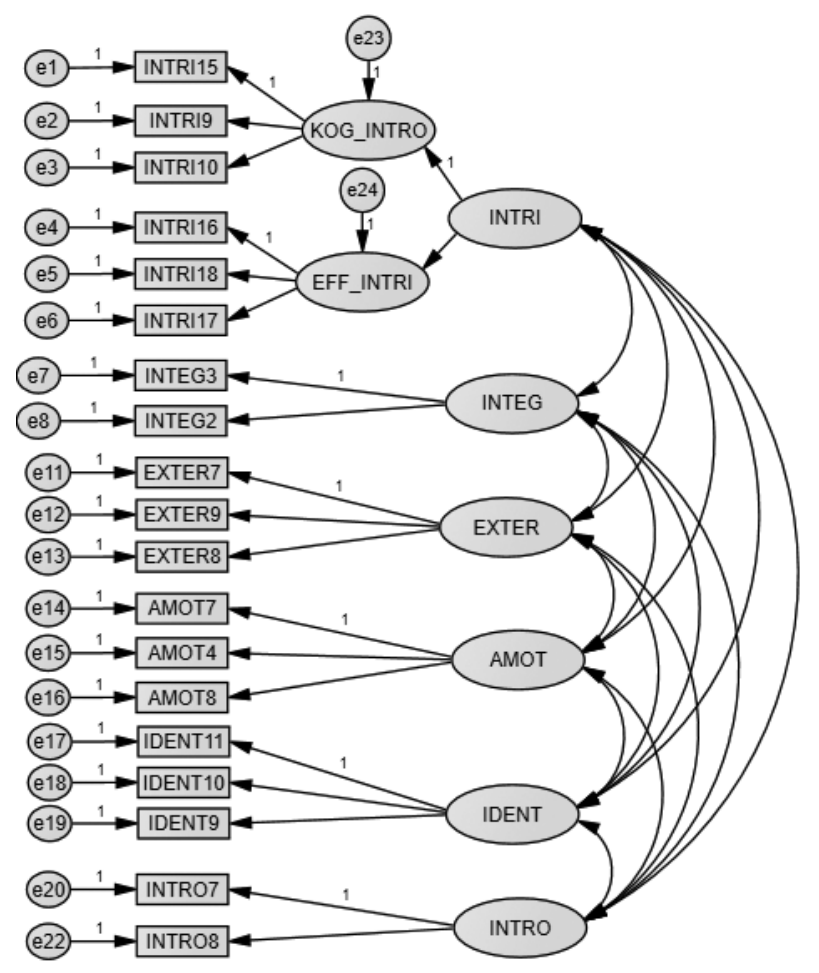

1. ábra. A végleges modell strukturális váza

Megjegyzés: INTRI6 = Intrinzik motiváció hat eleme együtt; E_INT = Effektív Intrinzik; K_INT = Kognitív Intrinzik; INTEG = Integrált; IDENT = Identifikált; INTRO = Introjektált; EXTR = Külsố szabályozás; AMOT = Amotiváció 
5. táblázat. A végsố modell megbízhatóságvizsgálatának eredménye

\begin{tabular}{|c|c|c|c|c|c|c|c|}
\hline \multirow[b]{2}{*}{ Változó } & \multicolumn{2}{|c|}{ INTRINZIK } & \multirow[b]{2}{*}{ INTEGRÁLT } & \multirow[b]{2}{*}{ IDENTIFIKÁLT } & \multirow[b]{2}{*}{ INTROJEKTÁLT } & \multirow[b]{2}{*}{ KÜLSŐ } & \multirow[b]{2}{*}{ AMOTIVÁCIÓ } \\
\hline & $\begin{array}{l}\text { EFFEKTÍV } \\
\text { INTRINZIK }\end{array}$ & $\begin{array}{l}\text { KOGNITÍV } \\
\text { INTRINZIK }\end{array}$ & & & & & \\
\hline INTRI18 & 0,84 & & & & & & \\
\hline INTRI16 & 0,83 & & & & & & \\
\hline INTRI17 & 0,75 & & & & & & \\
\hline INTRI9 & & 0,84 & & & & & \\
\hline INTRI15 & & 0,74 & & & & & \\
\hline INTRI10 & & 0,70 & & & & & \\
\hline INTEG2 & & & 0,86 & & & & \\
\hline INTEG3 & & & 0,82 & & & & \\
\hline INTEG4 & & & 0,76 & & & & \\
\hline INTEG5 & & & 0,78 & & & & \\
\hline IDENT11 & & & & 0,90 & & & \\
\hline IDENT10 & & & & 0,83 & & & \\
\hline IDENT9 & & & & 0,75 & & & \\
\hline INTRO8 & & & & & 0,91 & & \\
\hline INTRO7 & & & & & 0,68 & & \\
\hline INTRO9 & & & & & 0,61 & & \\
\hline EXTER9 & & & & & & 0,86 & \\
\hline EXTER7 & & & & & & 0,85 & \\
\hline EXTER8 & & & & & & 0,76 & \\
\hline AMOT4 & & & & & & & 0,84 \\
\hline AMOT8 & & & & & & & 0,80 \\
\hline AMOT7 & & & & & & & 0,65 \\
\hline $\begin{array}{l}\text { Cronbach } \\
\text { alfa }\end{array}$ & 0,82 & 0,84 & 0,85 & 0,85 & 0,79 & 0,85 & 0,80 \\
\hline CR & & & 0,85 & 0,85 & 0,80 & 0,86 & 0,85 \\
\hline AVE & & & 0,74 & 0,64 & 0,68 & 0,66 & 0,85 \\
\hline
\end{tabular}

Megjegyzés: $\mathrm{CR}$ = fogalmi megbízhatósági mutató, AVE = átlagos magyarázott variancia. A dôlt betûvel szedett változók a megerôsítô faktoranalízis illeszkedésvizsgálata során kiestek a modellbôl.

Ahhoz, hogy még jobban alátámasszuk azon döntésünket, miszerint a másodrangú modellt támogatjuk, vizsgálat alá vontuk az egyes sportágak tekintetében is az effektív és a kognitív tanulás iránti intrinzik motivációt. Ennek eredményeit a 6 . táblázat foglalja össze. Az összehasonlításhoz Wilcoxon-próbát használtunk, mivel a mért skála nem normál eloszlást követ, de az egyértelmúség kedvéért a mért változók átlaga közötti különbséget tüntettük fel a rangátlagok helyett.

A validáció egyik végsố lépéseként megvizsgáltuk, hogy az általunk véglegesnek ítélt H-SMS skála nemek közötti eloszlása miképpen alakul. Megállapítható, hogy a 
6. táblázat. Az intrinzik motiváció két dimenziójának különbségei az egyes sportágak vonatkozásában

\begin{tabular}{lccccc}
\hline Sportág & $\begin{array}{c}\text { Effektív } \\
\text { intrinzik }\end{array}$ & $\begin{array}{c}\text { Kognitív } \\
\text { intrinzik }\end{array}$ & Különbség & $\mathrm{Z}$ & sig \\
\hline Kézilabdázás $(\mathrm{n}=81)$ & 4,89 & 5,39 & 0,50 & $-3,97$ & $<\mathbf{0 , 0 0 1}$ \\
Kosárlabdázás $(\mathrm{n}=47)$ & 4,37 & 4,86 & 0,49 & $-3,37$ & $<\mathbf{0 , 0 0 1}$ \\
Labdarúgás $(\mathrm{n}=136)$ & 4,48 & 4,85 & 0,36 & $-3,87$ & $<\mathbf{0 , 0 0 1}$ \\
Röplabdázás $(\mathrm{n}=18)$ & 4,61 & 4,93 & 0,32 & $-1,21$ & 0,158 \\
Vízilabdázás $(\mathrm{n}=31)$ & 4,26 & 4,62 & 0,36 & $-1,56$ & 0,082 \\
Egyéb csapatsport $(\mathrm{n}=17)$ & 5,16 & 5,45 & 0,29 & $-1,49$ & 0,341 \\
Úszás $(\mathrm{n}=32)$ & 4,37 & 4,88 & 0,51 & $-3,02$ & $\mathbf{0 , 0 0 3}$ \\
Küzdősportok $(\mathrm{n}=26)$ & 5,38 & 5,73 & 0,35 & $-1,70$ & 0,128 \\
Aerobic, tánc $(\mathrm{n}=12)$ & 5,11 & 4,91 & $-0,20$ & $-0,32$ & 0,606 \\
Tenisz $(\mathrm{n}=12)$ & 4,08 & 4,78 & 0,70 & $-1,50$ & 0,123 \\
Torna $(\mathrm{n}=9)$ & 5,63 & 5,78 & 0,15 & $-0,54$ & 0,665 \\
Egyéb egyéni sport $(\mathrm{n}=68)$ & 5,17 & 5,54 & 0,37 & $-3,12$ & 0,002 \\
\hline
\end{tabular}

7. táblázat. Az egyes motivációs tényezôk és a nemek kapcsolata

(Mann-Whitney U használatával)

\begin{tabular}{lccc}
\hline & \multicolumn{3}{c}{ Nem } \\
\cline { 2 - 4 } & Férfi $(\mathrm{n}=319)$ & Nő $(\mathrm{n}=181)$ & $\mathrm{Z}(\mathrm{p})$ \\
\hline Intrinzik & 4,87 & 4,95 & $-0,432(0,666)$ \\
Kognitív intrinzik & 5,05 & 5,18 & $-1,105(0,269)$ \\
Effektív intrinzik & 4,70 & 4,71 & $-0,279(0,780)$ \\
Integrált & 4,84 & 4,92 & $-0,520(0,603)$ \\
Identifikált & 4,69 & 4,93 & $-1,809(0,070)$ \\
Introjektált & 5,30 & 5,56 & $-1,902(0,057)$ \\
Külsố szabályozás & 2,67 & 2,44 & $\mathbf{- 2 , 1 9 9 ( 0 , 0 2 8 )}$ \\
Amotivált & 2,37 & 1,93 & $-2,674(0,008)$ \\
\hline
\end{tabular}

külsố szabályozás és az amotiváció faktorokban szignifikáns különbség figyelhetố meg a férfiak és a nôk között. Férfiaknál erôsebb a külsô szabályozás és az amotiváció is (7. táblázat).

Az életkori csoportok vizsgálatából pedig kiderül, hogy a belsô motiváció szintje az életkor eloorehaladtával csökken, valamint az intrinzik motiváció kognitív faktora minden életkori csoportban magasabb, mint az effektív faktor. Az amotiváció legalacsonyabb értéke a legfiatalabb életkorú mintára jellemzô, az életkor növekedésével pedig egyre magasabb. A külsố motiváció külsố szabályozás faktora pedig elôször nô, viszont a 35 év feletti korosztálynál újfent csökken (8. táblázat).

Az utolsó, 9. táblázatból pedig leolvasható, hogy a vizsgált minta alapján a belsôleg leginkább motivált sportolóknak a kézilabdázók bizonyultak, míg a vízilabdázók a legkevésbé motiváltak. 
8. táblázat. Az egyes motivációs tényezôk és különbözó életkori csoportok kapcsolata a teljes mintán (Kruskall-Wallis használatával)

\begin{tabular}{lcccccccc}
\hline Korcsoport & INTRI6 & E_INT & K_INT & INTEG & IDENT & INTRO & EXTR & AMOT \\
\hline $\mathbf{1 5 - 1 7}(\mathbf{n}=\mathbf{1 1 4})$ & 5,10 & 4,87 & 5,32 & 4,85 & 4,87 & 5,72 & 2,21 & 1,73 \\
$\mathbf{1 8 - 1 9}(\mathbf{n}=\mathbf{1 4 5})$ & 5,00 & 4,80 & 5,20 & 4,92 & 4,89 & 5,34 & 2,85 & 2,19 \\
$\mathbf{2 0 - 2 3}(\mathbf{n}=\mathbf{1 5 8})$ & 4,98 & 4,78 & 5,17 & 4,91 & 4,73 & 5,25 & 2,46 & 2,27 \\
$\mathbf{2 4 - 3 5}(\mathbf{n}=\mathbf{6 1})$ & 4,28 & 4,09 & 4,46 & 4,86 & 4,55 & 5,18 & 3,09 & 2,65 \\
$\mathbf{3 5}+(\mathbf{n}=\mathbf{2 2})$ & 4,28 & 4,23 & 4,35 & 4,22 & 4,28 & 5,65 & 2,27 & 2,19 \\
$\boldsymbol{\chi}^{2}$ & 17,73 & 12,71 & 19,75 & 2,657 & 4,77 & 12,00 & 15,75 & 19,93 \\
$\mathbf{s i g}$ & $\mathbf{0 , 0 0 1}$ & $\mathbf{0 , 0 1 3}$ & $\mathbf{0 , 0 0 1}$ & 0,617 & 0,312 & $\mathbf{0 , 0 1 7}$ & $\mathbf{0 , 0 0 3}$ & $\mathbf{0 , 0 0 1}$ \\
\hline
\end{tabular}

9. táblázat. Az egyes motivációs tényezôk és a különbözô csapatsportágak kapcsolata

\begin{tabular}{|c|c|c|c|c|c|c|}
\hline & $\begin{array}{l}\text { Kézilabdázás } \\
\quad(\mathrm{n}=81)\end{array}$ & $\begin{array}{l}\text { Kosárlabdázás } \\
\quad(\mathrm{n}=47)\end{array}$ & $\begin{array}{l}\text { Labdarúgás } \\
(\mathrm{n}=136)\end{array}$ & $\begin{array}{c}\text { Röplabdá- } \\
\text { zás } \\
(\mathrm{n}=18) \\
\end{array}$ & $\begin{array}{l}\text { Vízilabdázás } \\
(\mathrm{n}=31)\end{array}$ & $\chi^{2}(\mathrm{p} ; \mathrm{df}=4)$ \\
\hline Intrinzik & 5,14 & 4,61 & 4,66 & 4,77 & 4,44 & $10,664(0,031)$ \\
\hline $\begin{array}{l}\text { Kognitív } \\
\text { intrinzik }\end{array}$ & 5,38 & 4,85 & 4,84 & 4,93 & 4,62 & $11,728(0,019)$ \\
\hline $\begin{array}{l}\text { Effektív } \\
\text { intrinzik }\end{array}$ & 4,89 & 4,36 & 4,48 & 4,61 & 4,26 & $7,549(0,110)$ \\
\hline Integrált & 5,00 & 4,90 & 4,81 & 4,61 & 4,08 & $7,396(0,116)$ \\
\hline Identifikált & 5,04 & 4,62 & 4,60 & 4,43 & 4,26 & $10,051(0,040)$ \\
\hline Introjektált & 5,73 & 5,13 & 5,30 & 4,97 & 5,33 & $12,499(0,014)$ \\
\hline Extrinzik & 2,57 & 2,81 & 2,99 & 2,93 & 1,97 & $15,170(0,004)$ \\
\hline Amotivált & 1,99 & 2,50 & 2,55 & 1,98 & 1,94 & $11,313(0,023)$ \\
\hline
\end{tabular}

\section{MEGVITATÁS}

Az általunk kialakított H-SMS skála, amellett, hogy megfelel a validitás minden kritériumának, nagyrészt megtartotta az eredeti faktorstruktúrát, de eredményeiben több különbséget is találunk az eredeti verzióhoz képest. Ezen különbségek egyike az észlelt kompetenciára (kognitív) és az önhatékonyság növelésére (effektív) irányuló intrinzik motiváció alfaktorainak bevezetése, amelyet a jobb illeszkedésvizsgálati mutatók mellett több egyéb eredmény is alátámasztott.

A végsố skála esetében észrevehetô (4. és 5. táblázat), hogy az intrinzik motiváció erôs korrelációt mutat a többi külsố motivációs tényezôvel, így az integrált, az identifikált és az introjektált faktorokkal. Emellett nem korrelál a külsố szabályozással, valamint az is kitûnik, hogy ellentétes irányú kapcsolat mutatható ki az intrinzik motiváció és az amotiváció között. Így fontos visszatérnünk arra a tényre, hogy Pelletier és munkatársai (2013) kutatásában a faktorok belsố korrelációja minden esetben magasabb volt a külsố motivációt mérô változók között, mint a mi modellünk esetében. Igaz ez egyrészt az intrinzik és az extrinzik motivációs tényezókre, másrészt az extrinzik tényezôk egymás közötti viszonyára is. Számunkra ez azt jelenti, hogy az egyes faktorok értelmezésükben jobban elválnak a magyar modellben, mint az eredetiben. További különbség, hogy esetünkben erôsebb a negatív irányú kapcsolat az amotiváció és intrinzik, valamint az introjektált motiváció között. Viszont az eredeti modellel ellentét- 
ben esetünkben nem találunk szignifikáns negatív irányú korrelációt az integrált és az identifikált szabályozás között. Szintén különbség, hogy az introjektált és külsô szabályozás között nem lehet szignifikáns kapcsolatot találni, viszont szignifikáns kapcsolat látszik az identifikált és a külsố motiváció külsô szabályozás faktora vonatkozásában. További kutatások során fel kell térképezi a különbségek mögött húzódó okokat, különösen annak ismeretében, hogy felmérésünkben az introjektált motívumok kapták a legmagasabb átlagot, míg az eredeti kutatásban ez volt a legalacsonyabb. A magyar és az eredeti felmérés közötti különbség 1,35 pont (5,40 és 4,05) a magyar minta ,javára”. A többi faktor esetében a különbségek: -0,07; 0,12; -0,43; -0,09 és 0,30.

A 6. táblázat alapján jól látszik, hogy az effektív tanulással kapcsolatos intrinzik motiváció a vízilabdázás kivételével az összes olyan esetben szignifikáns különbséget mutat, ahol a mintaelemszám meghaladja a 30-at. Emellett az is látszik, hogy ezekben az esetekben rendre a kognitív tanulás iránti motiváció a domináns. Van azonban két olyan sportág, amelyik eltér az átlagtól. Ezek közül az egyik esetében a különbség nagyon kicsi (torna), míg a másik az egyetlen olyan sportág a felmérésünkben, amely során a technikai elemek elsajátításával kapcsolatos effektív motiváció magasabb, mint a kognitív tanulás. Ez a sport - nem meglepô módon - a tánc. Mindezek még inkább megerôsítettek bennünket, hogy jó megoldás az effektív és a kognitív tanulás iránti intrinzik motivációk szétválasztása.

A nemek és az életkor esetében a kognitív dimenzió minden esetben magasabb értékeket mutat, mint az effektív. Ezen felül az önmeghatározott külsô motivációs faktorok (integrált és identifikált szabályozás) is csökkenô tendenciát mutatnak, amely megegyezik a nemzetközi kutatásokban megfigyeltekkel. Ugyanígy, az introjektált szabályozás faktor relatíve magas értékei összhangban állnak ezen korábbi kutatások eredményeivel (Doganis, 2000; Nuñez és mtsai, 2006; Bara és mtsai, 2011; Burtscher és mtsai, 2011). Az extrinzik motiváció külsô szabályozás faktorának eredménye a labdarúgók esetében volt a legmagasabb, míg a legalacsonyabb érték a vízilabdázók mintáján volt megfigyelhetô. Az amotiváció értékei pedig megegyeztek a külsô szabályozás tendenciával.

\section{ÖSSZEGZÉS}

A sportmotiváció hazai és nemzetközi viszonylatban is széleskörúen kutatott téma. Az egyik legelterjedtebb kérdőív a sportolók és nem sportolók sportmotivációjának felmérésére az önmeghatározás elméletére és annak fizikai aktivitás kontextusának keretrendszerére alapozó Sportmotivációs Skála (SMS). Az SMS skála egy önmeghatározott külsố motivációs faktor (integrált szabályozás) hiányában nem alkalmazta az önmeghatározás elméletének egzakt kontinuumát, ezért a szerzók egy újabb skála létrehozásával igyekeztek pótolni e hiányosságot (SMS2). A magyar kutatók szerteágazó vizsgálatok során használták a Sportmotivációs Skála elsô változatának validált formáját, amely az elméleti keretrendszer 3 faktorát mérte. Ezért születtek próbálkozások a skála magyar nyelvú verziójának teljeskörú validálására. Valószínúsíthetô, hogy a magyar nyelv sajátosságai és a magyarok gondolkodásának eltérései miatt nem voltak sikeresek e kísérletek. Munkánkban és jelen tanulmányunkban e hiány pótlását céloz- 
tuk meg a Sportmotivációs Skála validálási eljárásának bemutatásával. Az átgondolt, és a korábbi magyar módszertani megoldásoktól eltéróen felépített kutatás sikeresnek bizonyult, melynek eredményeként az újonnan létrehozott magyar sportmotivációs skála (H-SMS) teljeskörúen alkalmas a hazai sportolói kontextusban végzett sportmotivációs kutatások lebonyolítására, valamint azok eredményeinek nemzetközi kutatásokkal való összehasonlítására.

\section{A kutatás korlátai és jövóbeli irányai}

A kutatás korlátai között megemlíthetô a mintavétel módja, amely papír alapú kérdőívekre szúkült és torzíthatja a kutatási minta eredményeit. Annak érdekében, hogy pontosabb képet kaphassunk, célszerú a modell helyességét további sportágak esetében is bizonyítani, valamint a versenyszerú és az szabadidôs/rekreációs sportolók sportmotivációs mutatóival is összevetni. A jelen kutatás eredményeiból a sportági elemszámok nem egyenletes eloszlása, a területileg behatárolt minta (Dél-Dunántúl) és egyes sportágak alacsony elemszámai következtében nem vonhatunk le általános, minden sportágra érvényes következtetéseket.

A kutatás jövôbeni irányainak tekinthetô a kérdőív specializáltabb mintán történô tesztelése további egyéni és csapatsportágak tekintetében, valamint a korosztályok célirányosabb tagolását kialakítva. Célszerú lenne a sportágak magasabb elemszámú vizsgálatával is alátámasztani vagy cáfolni a jelen kutatásban megfogalmazott feltevéseket. Mindezen felül területi elosztásban is érdemes megvizsgálni az azonosságokat és különbségeket, amelyek eredményei segíthetik az edzók munkája mellett az utánpótlás-nevelés sikerességét is. Továbbá a jövoóben érdemes megvizsgálni a kérdôív konvergens, divergens és prediktív validitását (különösen a PMCSQ-2, EDMCQ, valamint a feladat- és énközpontú viselkedés kapcsán), illetve a válaszok időbeli stabilitását.

\section{Hozzájárulás, köszönetnyilvánítás}

A jelen tudományos közleményt a szerzôk a Pécsi Tudományegyetem alapítása 650. évfordulója emlékének szentelik.

A tanulmány a GINOP 2.3.2-15-2016-00047 „Analitikai és diagnosztikai kutatási kiválósági központ az egészség és a sportteljesítmény szolgálatában” projekt keretében került megvalósításra.

\section{IRODALOMJEGYZÉK}

Bagozzi, R. P., \& Yi, Y. (1988). On the evaluation of structural equation models. Journal of the Academy of Marketing Science, 16, 74-94.

Banville, D., Desrosiers, P., \& Genet-Volet, Y. (2000). Translating questionnaires and inventories using a cross-cultural translation technique. Journal of Teaching in Physical Education, 19(3), 374-387. 
Bara, F. M., Andrade, D., Miranda, R., Núñez, J. L., Martín-Albó, J., \& Ribas, P. R. (2011). Preliminary validation of a Brazilian version of the sport motivation scale. Universitas Psychologica, 10(2), 557-566.

Baumgartner, H., \& Hombur, C. (1996). Applications of structural equation modeling in marketing and consumer research: A review. International Journal of Research in Marketing, 13(2), 139-161.

Benczenleitner O., Bognár J., Révész L., Paksi J., Csáki I., \& Géczi G. (2013). Motivation and motivational climate among elite hammer throwers. Biomedical Human Kinetics, 5, 6-10.

Bentler, P. M. (1990). Comparative fit indexes in structural models. Psychological Bulletin, 107, 238-246.

Bentler, P. M., \& Chou, C. P. (1987). Practical Issues in Structural Modeling. Sociological Methods and Research, 16(1), 78-117.

Bognár J., Géczi G., Vincze G., \& Szabó A. (2009). Coping skills, motivational profiles, and percieved motivational climate in young elite ice hockey and soccer players. International Quarterly of Sport Science, 1, 1-11.

Bollók S., Takács J., Kalmár Zs., \& Dobay B. (2011). External and internal sport motivations of young adults. Biomedical Human Kinetics, 3, 101-105.

Bouchard, C., Blair, S., \& Haskell, W. (2007). Physical activity and health. Champaign: Human Kinetics.

Brière, N., Vallerand, R. J., Blais, M., \& Pelletier, L. G. (1995). Développement et validation d'une mesure de motivation intrinsèque et extrinsèque et d'amotivation en contexte sportif: L'Echelle de Motivation dans les Sports (EMS). International Journal of Sport Psychology, 26, 465-489.

Burtscher, J., Furtner, M., Sachse, P., \& Burtscher, M. (2011). Validation a German version of the sport motivation scale (SMS28) and motivation analysis in competitive mountain runners. Perceptual and Motor Skills, 112/3, 807-820.

Byrne, B. M. (2000). Structural equation modeling with AMOS: Basic concepts, applications, and programming. Mahwah: Lawrence Erlbaum Associates.

Camliguney, F. A., Mengutay, S., \& Pehlivan, A. (2012). Differences in physical activity levelsin 8-10 year-old girls who attended physical education classes only and those who also reguraly perform extracurricular physical activities. Procedia Social and Behavioral Science, 46, 4708-4712.

Carmines, E. G., \& McIver, J. P. (1981). Analyzing models with unobserved variables: Analysis of Covariance Structures. In: Bohrnstedt, G. W. \& Borgatta, E. F. (Eds), Social measurement: Current issues (pp. 65-115). Beverly Hills: Sage.

Chantal, Y., Guay, F., \& Dobreva Martinova, T. (1996). Motivation and elite performance: an exploratory investigation with Bulgarian athletes. International Journal of Sport Psychology, 27, 173-182.

Chatzisarantis, N., Hagger, M., Biddle, S., Smith, B., \& Wang, J. (2003). A meta-analysis of perceived locus of causality in exercise, sport, and physical education contexts. Journal of Sport Ẽ Exercise Psychology, 25, 284-306.

Chi, L., \& Duda, J. L. (1995). Multi-sample confirmatory factor analysis of the task and ego orientation in sport questionnaire. Research Quarterly Exercise and Sport, 66, 91-98.

Clark, L. A., \& Watson D. (1995). Constructing Validity: Basic Issues in Objective Scale Development. Psychological Assesment. 7(3), 309-319.

Conners, K. C., Sitarenios, G., Parker, J. D. A., \& Epstein, J. N. (1998). The Revised Conners' Parent Rating Scale (CPRS-R): Factor Structure, Reliability, and Criterion Validity. Journal of Abnormal Child Psychology, 25, 256-268. 
Cresswell, S., \& Eklund, R. (2005). Motivation and burn out among top amateur rugby players. Medicine and Science in Sports and Exercise, 37, 469-477.

Csáki I., Fózer-Selmeci B., Bognár J., Szájer P., Zalai D., Géczi G. (2016). Új mérési módszer: Pszichés tényezôk vizsgálata a Vienna Test System segítségével labdarúgók körében. Testnevelés, Sport, Tudomány, 1/1, 8-20.

Deci, E. L., \& Ryan, R. M. (1985). Intrinsic motivation and self-determination in human behavior. New York: Plenum.

Deci, E. L., \& Ryan, R. M. (2000). The "what" and "why" of goal pursuits: human needs and the self-determination of behavior. Psychological Inquiry, 11, 227-268.

Diener, E., Emmons, R. A., Larsen, R. J., \& Griffin, S. (1985). The satisfaction with life scale. Journal of Personality Assessment, 49, 71-75.

Dishman, K. R., \& Buckworth, J. (2001). Exercise Psychology. In: Williams, J. M. (Ed.), Applied Sport Psychology: personal growth to peak performance (pp. 497-518). Houston: Mayfield Publishing Company.

Doganis, G. (2000). Development of a Greek version of the sport motivation scale. Perceptual and Motor Skills, 90, 505-512.

Duda, J. L. (1989). Relationship between task and ego orientation and the perceived purpose of sport among high school athletes. Journal of Sport and Exercise Psychology, 11, 318-335.

Fornell, C., \& Larcker, D. F. (1981). Structural equation models with unobservable variables and measurement error: Algebra and statistics. Journal of Marketing Research (JMR), 18(3), 382-388.

Géczi G., Vincze G., Koltai M., \& Bognár J. (2009). Elite young team sport players' coping, motivation and perceived climate measures. Physical Culure and Sport Studies and Research, 46, 229-242.

García Calvo T., Cervelló E., Jimenéz, R., Iglesias, D., \& Moreno Murcia, C. A. (2010). Using Self-Determination Theory to Explain Sport Persistence and Dropout in Adolescent Athletes. The Spanish Journal of Psychology, 13/2, 677-684.

Gyömbér N., \& Kovács K. (2012). Fejben dól el - Sportpszichológia mindenkinek. Budapest: Nolan Libro.

Hagger, M. S., \& Chatzisarantis, N. (2007). Intrinsic motivation and self-determination in exercise and sport. Leeds: Human Kinetics Europe Ltd.

Hair, J. F., Black, W. C., Babin, B. J., Anderson, R. E., \& Tatham, R. L. (2010). Multivariate data analysis (Vol. 5), New York: Pearson Prentice Hall.

Hooper, D., Coughlan, J., \& Mullen, M. R. (2008). Structural equation modelling: Guidelines for determining model fit. Journal of Business Research Methods, 6(1), 53-60.

Hu, L., \& Bentler, P. M. (1999). Cutoff criteria for fit indexes in covariance structure analysis: Conventional criteria versus new alternatives. Structural Equation Modeling, 6(1), 1-55.

Jackson, S., Ford, S., Kimiecik, J. C., \& Marsh, H. (1998). Psychological correlates of flow in sport. Journal of Sport E Exercise Psychology, 20, 358-378.

Járai R. (2004). Nemi különbségek a sport motivációban: Klasszifikációs fa elemzés. Pszichológia, $3,305-314$.

Járai R. (2006). Szelf determináció és tehetség kapcsolata fiatal sportolóknál. Tézisgyújtemény. Pécs: Pécsi Tudományegyetem.

Kavussanu, M., Stanger, N., \& Boardley, I. (2013). The Prosocial and Antisocial Behaviour in Sport Scale: further evidence for construct validity and reliability. Journal of Sport Sciences, 31/11, 1208-1221.

Kline, R. B. (2016). Principles and practice of structural equation modeling (4th ed.). New York: Guilford. 
Li, F., \& Harmer, P. (1996). Testing the simplex assumption underlying the sport motivation scale. Research Quarterly for Exercise and Sport, 67, 396-405.

Li, C., Kawabata, M., \& Zhang, L. (2016). Validity and reliability of the Sport Motivation Scale-II for Chinese athletes. International Journal of Sport and Exercise Psychology, 3, 1-14.

Lonsdale, C., Hodge, K., \& Rose, E. A. (2008). The behavioral regulation in sport questionnaire (BRSQ): instrument development and initial validity evidence. Journal of Sport and Exercise Psychology, 30, 323-355.

Lyden, P., Lu, M., Jackson, C., Marler, J., Kothari, R., Brott, T., et al. (1999). Underlying structure of the National Institutes of Health Stroke Scale. Stroke, 30, 2347-2354.

Mageau, G., \& Vallerand, R. J. (2003). The coach and athlete relationship: a motivational model. Journal of Sports Sciences, 21, 883-904.

Malhotra, N. K., \& Simon J. (2008). Marketingkutatás. Budapest: Akadémiai kiadó

Mallett, C., Kawabata, M., Newcombe, P., Otero-Forero, A., \& Jackson, S. (2007). Sport motivation scale-6 (SMS-6): a revised six-factor sport motivation scale. Psychology of Sport and Exercise, $8,600-614$.

Marsh, H. W., \& Hocevar, D. (1985). Application of confirmatory factor analysis to the study of self-concept: First- and higher-order factor models and their invariance across groups. Psychological Bulletin, 97, 562-582.

Mészáros V., Csigás Z., Ádám Sz., Hevesi K., \& Oláh A. (2014). Kognitív Gondolkodás Kérdôív (CTI) - A kérdôiv hazai adaptálásával kapcsolatos elsô tapasztalatok. Alkalmazott Pszichológia, 14(3), 73-88.

Mikulán R., \& Pikó B. (2012). Iskoláskorú sportoló fiatalok káros szenvedélyeinek vizsgálata sportmotivációik és a sportáguk típusa tükrében. Iskolakultúra, 4, 35-50.

Munkácsi I., Kalmár Zs., Hamar P., Katona Zs., \& Dancs H. (2012). Role of motivation in artistic gymnastics by results of a questionnaire based international survey. Journal of Human Sport E्F Exercise, 7(1), 91-102.

Münnich Á., \& Hidegkuti I. (2012). Strukturális egyenletek modelljei: Oksági viszonyok és komplex elméletek vizsgálata pszichológiai kutatásokban. Alkalmazott Pszichológia, 12(1), 77-102.

Neumann-Bódi E. (2012). Vevôértékelés egyéni és szervezeti vásárlók esetében. Doktori értekezés. Budapest: Corvinus Egyetem.

Nuñez, J., Albo, J., Navarro, J., \& Gonzalez, V. (2006). Preliminary validation of a Spanish version of the sport motivation scale. Perceptual and Motor Skills, 102, 919-930.

Paic R., Kajos A., \& Prisztóka Gy. (2016). A magyar nyelvú Sportmotiváció Skála II (SMS-II) elôzetes validációja. Magyar Sporttudományi Szemle, 17(66), 50.

Pelletier, L. G., Fortier, M. S., Vallerand, R. J., Tuson, K. M., Brière, N. M., \& Blais, M. R. (1995). Toward a new measure of intrinsic motivation, extrinsic motivation, and amotivation in sports: the Sport Motivation Scale (SMS). Journal of Sport and Exercise Psychology, 17, 35-53.

Pelletier, L., Fortier, M., Vallerand, R., \& Brière, N. (2001). Associations among perceived autonomy support, forms of self-regulation, and persistence: a prospective study. Motivation and Emotion, 25, 279-306.

Pelletier, L. G., \& Dion, S. (2007). An examination of general and specific motivational mechanisms for the relationships between body dissatisfaction and eating behaviors. Journal of Social and Clinical Psychology, 26, 303-333.

Pelletier, L., Vallerand, R., \& Sarrazin, P. (2007). Measurement issues in self-determination theory and sport. In: Chatzisarantis, N. \& Hagger, M. S. (Eds), Intrinsic motivation and selfdetermination in exercise and sport (pp. 143-152). Champaign, IL: Human Kinetics. 
Pelletier, L., \& Sarrazin, P. (2007). The revised six-factor sport motivation scale (Mallett, Kawabata, Newcombe, Otero-Forero, \& Jackson, 2007): something old, something new, and something borrowed. Psychology of Sport and Exercise, 8, 615-621.

Pelletier G. L., Rocchi M. A., Vallerand R. J., Deci E. L., \& Ryan M. R. (2013). Validation of the revised sport motivation scale (SMS-II). Psychology of Sport and Excercise, 14, 329-341.

Petrides, K. V., \& Furnham, A. (2000). On the dimensional structure of emotional intelligence. Personality and Individual Differences, 29, 313-320.

Roberts, G. C. (1992). Motivation in Sport and Exercise: Conceptual Constrains and Convergence. In: Roberts, G. C. (Ed.), Motivation in Sport and Exercise (pp. 3-29). Champaign, IL: Human Kinetics.

Ryan, R. M., \& Deci, E. L. (2007). Active human nature: Self-determination theory and the promotion and maintenance of sport, exercise, and health. In: Hagger, M. S. \& Chatzisarantis N. L. D. (Eds), Intrinsic motivation and self-determination in exercise and sport (pp. 1-19). Champaign, IL: Human Kinetics.

Ryan, R. M., \& Frederick, C. M. (1997). On energy, personality, and health: subjective vitality as a dynamic reflection of well-being. Journal of Personality, 65, 529-565.

Sajtos L., \& Mitev A. (2007). SPSS Kutatási és adatelemzési kézikönyv. Budapest: Alinea Kiadó

Sarrazin, P., Boiché, J., \& Pelletier, L. (2007). A Self-determination theory approach to dropout in athletes. In: Hagger, M. S. \& Chatzisarandis, N. L. D. (Eds), Intrinsic motivation and self-determination in exercise and sport (pp. 229-241). Champaign, IL: Human Kinetics.

Standage, M., Duda, J., \& Ntoumanis, N. (2003). A model of contextual motivation in physical education: using constructs from self-determination and achievement goal theories to predict physical activity intentions. Journal of Educational Psychology, 95, 97-110.

Standage, M., \& Ryan, R. M. (2012). Self-determination theory and exercise motivation: facilitating self-regulatory processes to support and maintain health and well-being. In: Roberts, G. C. \& Treasure, D. C. (Eds), Advances in motivation in sport and exercise (3rd ed.) (pp. 233-270). Champaign, IL: Human Kinetics.

Szemes Á., \& Harsányi Sz. G. (2015). Sportmotiváció és flow élmény vizsgálata társastáncok körében. Magyar Sporttudományi Szemle, 61, 21-28.

Szemes Á., Harsányi Sz. G., \& Tóth L. (2016). Különbözô sportágakban versenyzô sportolók sportmotivációjának és flow élményének összehasonlító vizsgálata. Testnevelés, Sport, Tudomány, 1, 80-90.

Szemes Á., Vig P., Géczi G., Patócs Á., Sipos K., \& Tóth L. (2017). Különbözô életkorú élvonalbeli birkózók észlelt motivációs környezetének és külsô-belsô motivációs tényezőinek összehasonlító vizsgálata. Magyar Sporttudományi Szemle, 18(69) 37-43.

Tóth L. (2015). A motiváció mint folyamat komplex értelmezése az iskolai Testnevelés és sport múveltségi terület keretében. In: Révész, L. \& Csányi, T. (Eds), Tudományos alapok a testnevelés tanításához (pp. 105-134). Budapest: Magyar Diáksport Szövetség.

Tsang, E. C. K., Szabo, A., Soos, I., \& Bute, P. (2005). A study of cultural differences in motivational orientations towards sport participation of junior secondary school children in four cultures. Journal of Physical Educations and Recreations, 11(1), 44-50.

Vallerand, R. J. (1989). Vers une me thodologie de validation trans-culturelle de questionnaires psychologiques: Implications pour la recherche en langue française [Toward a methodology of cross-cultural validation of psychological questionnaires: Implications for research in French]. Psychologie Canadienne, 30(4), 662-680.

Vallerand, R. J. (1997). Toward a hierarchical model of intrinsic and extrinsic motivation. In: Zanna, M. P. (Ed.), Advances in experimental social psychology (pp. 29., 271-360). New York: Academic Press. 
Vallerand, R. J. (2007). Intrinsic and extrinsic motivation in sport and physical activity: a review and a look at the future. In: Tennenbaum, G. \& Eklund, R. (Eds), Handbook of sport psychology (3rd ed.) (pp. 59-83). New York: John Wiley \& Sons.

Vallerand, R. J., Pelletier, L. G., Blais, M. R., Brière, N. M., Sènècal, C., \& Vallibres, E. F. (1992). The Academic Motivation Scale: A measure of intrinsic, extrinsic, and arnotivation in education. Educational and Psychological Measurement, 52, 1003-1017.

Weinberg, R. S., \& Gould, D. (2011). Foundations of sport and exercise psychology. Champaign: Human Kinetics

Zahariadis, P., Tsorbatzoudis, H., \& Grouis, G. (2005). The sport motivation scale for children: preliminary analysis in physical education classes. Perceptual and Motor Skills, 101, 43-54.

Zamboni, D., Crawford, I., \& Carrico, A. (2008). Predictors of sports motivation among gay and bisexual men. Journal of Homosexuality, 54, 449-468.

\section{THE VALIDATION AND RESUTS OF THE HUNGARIAN SPORT MOTIVATION SCALE (H-SMS)}

\section{PAIC, RÓBERT - KAJOS, ATTILA - MESZLER, BALÁZS - PRISZTÓKA, GYÖNGYVÉR}

Background and aims: During the validation process of the translated SMS2 scale in 2016 we realized the problems caused by the specifics, characteristics and attributes of the Hungarian language. Moreover, the Hungarian athletes had different perceptions of some expressions. That is the reason why word by word translations of psychometric scales are not always possible. Thus we followed the original framework of Self-determination theory during the creation of the new Hungarian version of the Sport Motivation Scale (H-SMS).

Methods: We translated the original item pool (61 items) of the English SMS2 and adapted it on the $n=$ 500 sample of athletes from different sports. The sample built up from 319 male and 181 female athletes with an average age of 21,16 years $(S D=6,45)$.

Results: The H-SMS kept all the factors from the original SMS2 scale. In addition, we divided the intrinsic motivation factor to cognitive intrinsic (perceived competence) and effective intrinsic (self-effectiveness) subscales. As a result, the final scale contains 6 factors and 19 items. The final version, which we chose between two different models, fits all of the validity and reliability requirements of the psychometric scales $(C M I N / d f$ $=1,77 ;$ SRMSR =0,042; RMSEA =0,040; PCLOSE =0,983; NFI =0,953; TLI =0,973; CFI =0,979; Cronbach alfa =0,79-0,89; $C R=0,80-0,94 ; A V E=0,65-0,89 ; A V E>M S V)$.

Conclusions: Concerning all the results we can assume the Hungarian Sport Motivation Scale (H-SMS) can be used in order to measure the motivation towards sport of Hungarian athletes. Furthermore, its results are comparable with the relevant international studies.

Keywords: sport motivation, validity study, psychometric scale

A cikk a Creative Commons Attribution-NonCommercial 410 International License (https://creativecommons.org/licenses/by-nc/4.0) feltételei szerint publikált Open Access közlemény, melynek szellemében a cikk nem kereskedelmi célból bármilyen médiumban szabadon felhasználható, megosztható és újraközölhetô, feltéve, hogy az eredeti szerzô és a közlés helye, illetve a CC License és az esetlegesen végrehajtott módosítások feltüntetésre kerülnek. 


\section{1. melléklet. A H-SMS skála végsố kérdései}

Miért úzi a választott sportágát?

Kérjük gondoljon arra, hogy miért ûzi az Ön számára elsôdlegesen választott sportágat. Az alábbi skála segítségével, kérjük jelölje meg, mennyire igazak önre az egyes állítások azzal kapcsolatban, hogy jelenleg miért is úzi kifejezetten ezt a sportágat vagy végzi ezt a sporttevékenységet.

\begin{tabular}{c|c|c|c|c|c|c}
\hline $\begin{array}{c}\text { Egyáltalán } \\
\text { nem igaz } \\
\text { rám }\end{array}$ & $\begin{array}{c}\text { Egészen kis } \\
\text { mértékben } \\
\text { igaz rám }\end{array}$ & $\begin{array}{c}\text { Valamennyi- } \\
\text { re igaz rám }\end{array}$ & $\begin{array}{c}\text { Közepes } \\
\text { mértékben } \\
\text { igaz rám }\end{array}$ & $\begin{array}{c}\text { Inkább igaz } \\
\text { rám }\end{array}$ & $\begin{array}{c}\text { Nagy mérték- } \\
\text { ben igaz rám }\end{array}$ & $\begin{array}{c}\text { Teljes mér- } \\
\text { tékben igaz } \\
\text { rám }\end{array}$ \\
1 & 2 & 3 & 4 & 5 & 6 & 7 \\
\hline
\end{tabular}

1. Mert rosszul érezném magam, ha nem fordítanék rá idôt.

$\begin{array}{lllllll}1 & 2 & 3 & 4 & 5 & 6 & 7 \\ 1 & 2 & 3 & 4 & 5 & 6 & 7\end{array}$

2. Gyakran kérdezem én is magamtól, hogy miért csinálom még, mert már nem látom, hogy elérném a céljaimat, amiket kitûztem magam elé.

3. A nehéz mozgáskombinációk elvégzése közben érzett örömért.

4. Mert kifejezi a belsô értékeimet.

$\begin{array}{lllllll}1 & 2 & 3 & 4 & 5 & 6 & 7\end{array}$

5. Mert a számomra fontos embereket bosszantaná, ha nem csinál- 1 nám.

6. Mert az egyik legjobb módja annak, hogy fejlesszem személyisé- $\quad \begin{array}{lllllllllll}1 & 2 & 3 & 4 & & 5 & 6 & 7\end{array}$ gem más oldalait is

7. Mert örömöt okoz, hogy többet tanulok a sportágamról.

8. Mert a környezetemben lévô emberek megjutalmaznak érte.

9. Az eddig ismeretlen edzéstechnikák elsajátításakor érzett öröm miatt.

10. Olyan érzésem van, hogy már nem tudok sikeres lenni ebben $\begin{array}{lllllllllllll}1 & 2 & 3 & 4 & & 5 & 6 & 7\end{array}$ a sportágban.

11. Mert nagyon érdekes megtanulnom, hogy miként fejlődhetek. $\begin{array}{lllllllllll}1 & 2 & 3 & 4 & & 5 & 6 & 7\end{array}$

12. Mert ez a sport az önfejlesztésem egyik módja. $\quad \begin{array}{llllllllllll} & 2 & 3 & 4 & 5 & 6 & 7\end{array}$

13. Mert azonos a belsô értékrendemmel. $\quad \begin{array}{llllllll} & 1 & 2 & 3 & 4 & 5 & 6 & 7\end{array}$

14. Mert élvezek új technikai elemeket megtanulni. $\quad \begin{array}{llllllllllll}4 & 2 & 3 & 4 & 5 & 6 & 7\end{array}$

15. Mert mások nem helyeselnék, ha nem csinálnám. $\quad \begin{array}{lllllllllllll} & 1 & 2 & 3 & 4 & 5 & 6 & 7\end{array}$

16. Mert jobb érzésem van magammal kapcsolatban, amikor csi- $\begin{array}{lllllllllllll}1 & 2 & 3 & 4 & & 5 & 6 & 7\end{array}$ nálom.

17. Már nem is egyértelmú számomra, hogy miért sportolok, nem $\quad \begin{array}{llllllllllll}1 & 2 & 3 & 4 & & 5 & 6 & 7\end{array}$ hiszem, hogy van helyem ebben a sportban.

18. Mert úgy gondolom ez egy jó módja a személyiségem értékes $\quad \begin{array}{lllllllllllll}1 & 2 & 3 & 4 & & 5 & 6 & 7\end{array}$ részeinek fejlesztésére.

19. Mert élvezem, ha új módszereket ismerhetek meg a teljesítmé- $\begin{array}{llllllllllll}1 & 2 & 3 & 4 & & 5 & 6 & 7\end{array}$ nyem növelésére.

\begin{tabular}{|c|c|c|c|c|c|c|}
\hline \multicolumn{2}{|c|}{ Intrinzik szabályozás } & \multirow{3}{*}{$\begin{array}{c}\begin{array}{c}\text { Integrált szabá- } \\
\text { lyozás }\end{array} \\
4,13\end{array}$} & \multirow{3}{*}{$\begin{array}{c}\begin{array}{c}\text { Identifikált } \\
\text { szabályozás }\end{array} \\
6,12,18\end{array}$} & \multirow{3}{*}{$\begin{array}{l}\text { Introjek- } \\
\text { tált szabá- } \\
\text { lyozás } \\
1,16\end{array}$} & \multirow{3}{*}{$\begin{array}{c}\text { Külsô szabá- } \\
\text { lyozás } \\
5,8,15\end{array}$} & \multirow{3}{*}{$\begin{array}{c}\text { Amotiváció } \\
\text { 2, 10, } 17\end{array}$} \\
\hline $\begin{array}{l}\text { Effektív int- } \\
\text { rinzik }\end{array}$ & $\begin{array}{l}\text { Kognitív int- } \\
\text { rinzik }\end{array}$ & & & & & \\
\hline $3,9,14$ & $7,11,19$ & & & & & \\
\hline
\end{tabular}

